\title{
A Steady-State Evaluation of Simple Organic Rankine Cycle (SORC) with Low-Temperature Grade Waste Heat Source
}

\author{
Ali H. Tarrad \\ Université de Lorraine, CNRS, LEMTA, Nancy, France \\ Email: ali.tarrad@univ-lorraine.fr
}

How to cite this paper: Tarrad, A.H. (2020) A Steady-State Evaluation of Simple Organic Rankine Cycle (SORC) with Low-Temperature Grade Waste Heat Source. Journal of Power and Energy Engineering, 8, 15-31.

https://doi.org/10.4236/jpee.2020.87002

Received: June 16, 2020

Accepted: July 27, 2020

Published: July 30, 2020

Copyright ( 2020 by author(s) and Scientific Research Publishing Inc. This work is licensed under the Creative Commons Attribution International License (CC BY 4.0).

http://creativecommons.org/licenses/by/4.0/

\begin{abstract}
The low-grade heat source recovery is usually constrained by the physical characteristics of the hot fluid medium. The present work focuses on the importance of energy recovery from low-temperature waste energy sources and its conversion to useful electrical power. The thermal performance analysis is based on the utilization of R-123, R-134a, R-290, R-245fa, R-1234ze-E, and $\mathrm{R}-1233 z d-E$ fluids in a simple organic Rankine cycle (SORC). A waste energy source from an industrial sector is suggested to be available at a temperature greater than $110^{\circ} \mathrm{C}$. A hypothetical organic Rankine cycle of $10 \mathrm{~kW}$ nominal heat recovery was implemented to evaluate the cycle performance. It operates at evaporation and condensation temperatures of $90^{\circ} \mathrm{C}$ and $45^{\circ} \mathrm{C}$, respectively. The selected vapor superheat degree at the expander entrance was $5^{\circ} \mathrm{C}-15^{\circ} \mathrm{C}$, and the liquid was subcooled by $5^{\circ} \mathrm{C}$ at the discharge port of condenser. The estimated first law cycle thermal efficiency fell in the range of $6.4 \%-7.7 \%$. The results showed that the thermal efficiencies of R-134a, R-123, R-245fa, R-1233zd-E, and R-1234ze-E were higher than that of R-290 by $10 \%-14 \%$, $11 \%-12 \%, 9 \%-12 \%, 4 \%-7 \%$ and $1 \%-3 \%$, respectively. R-1233zd-E, R-1234ze-E, and R-290 showed close thermal efficiency values, and it fell in the range of $6.7 \%-7 \%$ for the (SORC) at a superheat degree of $15^{\circ} \mathrm{C}$. At the same superheat degree, the corresponding range of thermal efficiency for R-134a, R-123 and R-245fa fell within 7.5\% - 7.7\%. R-134a possessed the highest net power output of the (SORC); it reached a value of $0.91 \mathrm{~kW}$ as predicted at $15^{\circ} \mathrm{C}$ superheat degree. Increasing the expander volumetric efficiency value by $10 \%$ improved the cycle thermal efficiency by $10 \%-12 \%$.
\end{abstract}

\section{Keywords}

Organic Rankine Cycle, Low Temperature, Waste Heat Source, Thermal Analysis 


\section{Introduction}

The waste heat sources categorize into three different zones depending on their temperature level. They are assigned as the low temperature in the range $\left(\mathrm{T}_{\text {waste }}<\right.$ $230)^{\circ} \mathrm{C}$, medium $\left(\mathrm{T}_{\text {waste }}=230-650\right)^{\circ} \mathrm{C}$ and high temperature $\left(\mathrm{T}_{\text {waste }}>650\right)^{\circ} \mathrm{C}$. The economic justification of the selection of the heat recovery systems depends on the temperature range and cleanliness of the waste heat sources. It also depends on the amount of waste heat; the system cost payback; and the cost of available energy from other sources, Thekdi and Nimbalkar (2014) [1].

Heating energy losses represent $25 \%-55 \%$ of the total energy use. In the industrial sector, there is a lot of waste heat available, often on low-temperature levels and on small to moderate thermal power scale. Organic Rankine cycle (ORC) is a technology that can convert thermal energy at relatively low temperatures in the range of $80^{\circ} \mathrm{C}-350^{\circ} \mathrm{C}$ to electricity. Thekdi and Nimbalkar (2014) [1] have pointed out that significant heat recovery opportunities are available from the waste heat sources in the temperature of $25^{\circ} \mathrm{C}-150^{\circ} \mathrm{C}$, representing more than $80 \%$ of the total estimated waste heat. The work of Badr et al. (1985) [2], Yamamoto et al. (2001) [3], and Chen et al. (2006) [4] concluded that for low-grade heat energy conversion system, the conventional steam Rankine cycle is not efficient enough and compactable; hence it is not an appropriate or economic option to be utilized.

There are several cycle configurations for (ORC), they are sub-critical, transcritical or super-critical, basic or regenerative, single pressure or dual-pressure cycles; they have been proposed, simulated and experimentally investigated, Tchanche et al. (2011) [5] and Vignesh et al. (2018) [6]. The basic and regenerative, sub-critical, and single pressure (ORC) systems have been intensively dealt with and are adopted in the practical field due to their allowable working pressure range and sizing, Le et al. (2014) [7] and Astolfi et al. (2017) [8]. Shengjun et al. (2011) [9] investigated the utilization of 16 different working fluids at $80^{\circ} \mathrm{C}$ $100^{\circ} \mathrm{C}$ in an organic Rankine cycle (ORC). Their study showed that isobutene demanded the lowest cost to produce electricity, and R-152 required the smallest area of heat exchanger per unit of output power, and it was more compactable.

Yuan and Zhang (2019) [10] studied eight candidate working fluids R-123, R-245fa, R-114, R-236ea, R-236fa, RC318, R-227ea and R-1234yf with a low heat source grade of $100^{\circ} \mathrm{C}-150^{\circ} \mathrm{C}$. They concluded that under the given operating conditions, the heat source temperature and its allowable minimum temperature at outlet port influence the state for optimal turbine inlet condition. Further, the critical temperature of working fluid represents another factor which affects the optimal condition state. Vankeirsbilck et al. (2011) [11] have found that (ORC) can be operated on low-temperature heat sources grades with low to moderate evaporation pressure, and still achieve a better performance than that of a steam cycle.

Datla et al. (2014) [12] analyzed the effect of R1233zd-E fluid as a drop-in for $\mathrm{R}-245 \mathrm{fa}$ into an existing $75 \mathrm{~kW}$ variable-speed, oil-free low temperature (ORC) system. They concluded that a drop in R-1233zd-E into R-245fa based (ORC) 
systems would enhance the performance by $10 \%$ over the existing system. Molés et al. (2014) [13] compared the performance of R-1233zd-E and R-1336mzz-Z, to R-245fa over a wide range of evaporating and condensing temperatures, and vapor superheat degrees. They found that R-1233zd-E would require $10.3 \%$ to $17.3 \%$ lower pump power and would provide up to $10.6 \%$ higher cycle efficiency than R-245fa over the examined range of cycle conditions. The turbine size for R-1233zd-E would be about 7.5\% to 10.2\% larger than for R-245fa.

Heberle et al. (2015) [14] examined an existing 5.5 MWe double-stage power plant in Kirchstockach, Germany. It is a geothermal power plant that operates based on the organic Rankine cycle (ORC) and circulates R-245fa for high and low turbine pressure levels. They built a simulation model and found that (ORC) units using R-134a, R-600a, or these fluids as a mixture component needs high power to run the feed pump. Li et al. (2016) [15] compared the performance of $\mathrm{CO} 2$ transcritical power cycles (T-CO2) and R-245fa organic Rankine cycles (ORC) using low-grade thermal energy to produce electricity. They concluded that under similar operating conditions and heat transfer assumptions, the thermal and exergy efficiencies of R-245fa (ORC) are both slightly higher than those of (T-CO2) ones. R-245fa will most likely be effective in an organic Rankine cycle (ORC) because of its relatively high critical temperature. Li et al. (2017) [16] investigated experimentally the performance of a small-scale organic Rankine cycle (ORC) system utilizing low-grade heat sources to generate electric power and circulates R-245fa as a working fluid. They found that waste heat source temperature and (ORC) pump speed were important parameters in determining system thermal efficiency and the component operations.

Kong et al. (2019) [17] analyzed numerically a $20 \mathrm{kWe} / \mathrm{R}-245 \mathrm{fa}$ organic Rankine cycle (ORC) with low-grade temperature heat sources. They varied the heat source temperature in a range of $80^{\circ} \mathrm{C}-110^{\circ} \mathrm{C}$. The pinch temperature difference between the heat source and the evaporating was in a range of $1^{\circ} \mathrm{C}-10^{\circ} \mathrm{C}$ with a condensing temperature of $40^{\circ} \mathrm{C}$. They concluded that the first and the second law efficiencies of the (ORC) cycle decreased with the increase of pinch value for a given value of heat source temperature. Surindra et al. (2019) [18] studied R-245fa, R-123, and their mixture with different ratios in a laboratory (ORC) with a heat source at $110^{\circ} \mathrm{C}$ and $120^{\circ} \mathrm{C}$ experimentally. The results indicated that the (ORC) system has better thermodynamic performance at $120^{\circ} \mathrm{C}$ heat source than that obtained from $110^{\circ} \mathrm{C}$. Moreover, the R123 fluid produces the highest (ORC) efficiency with values between 9.4\% and 13.5\%. Da Cunha and Souza (2020) [19] simulated a regenerative organic Rankine cycle with up to 4 extractions circulated R-134a as a working fluid. The examined evaporation temperature range was $60^{\circ} \mathrm{C}-100^{\circ} \mathrm{C}$ and superheated temperatures were $120^{\circ} \mathrm{C}$, $200^{\circ} \mathrm{C}$, and $300^{\circ} \mathrm{C}$. They concluded that the maximum thermal efficiency increases with the evaporation temperature and the number of extractions and decreases with the increase of the superheat temperature. The turbine output power showed an augmentation with increasing in the evaporation and superheat 
temperatures but decreases with the increase in extractions.

This work utilized a simple organic Rankine cycle (SORC) for the thermal performance evaluation of six organic fluids at a low temperature of waste energy source. The term (Simple) refers to the basic organic Rankine cycle without a regenerative heat exchanger. A hypothetical organic Rankine cycle of nominal heat recovery of $10 \mathrm{~kW}$ was implemented for the evaluation of the cycle performance. R-123, R-134a, R-245fa, R-1234ze-E, R-1233zd-E, and the hydrocarbon $\mathrm{R}-290$ organic fluids were examined at the boiling temperature $90^{\circ} \mathrm{C}$ and condensing at $45^{\circ} \mathrm{C}$. The working fluids were subjected to superheat and subcooled degrees of $5^{\circ} \mathrm{C}-15^{\circ} \mathrm{C}$ and $5^{\circ} \mathrm{C}$, respectively. The low-temperature waste heat source was suggested to be available at a temperature higher than $110^{\circ} \mathrm{C}$.

\section{Methodology}

\subsection{Organic Fluids}

The selection of the working fluids has a vital role in system efficiency and environmental impacts. In the efficiency issue, the organic fluid should have favourable thermal properties and the capacity of absorbing the energy from the heat source with a low pinch temperature difference between a waste stream and the organic fluid. The critical point characteristics, pressure, and temperature also play a significant role in the working fluids' selection philosophy. Further, the fluid has to possess attractive global warming potential (GWP) and Ozone depletion potential (ODP). R-134a used in geothermal power plants or very low-temperature waste heat recovery and R-245fa is a low temperature working fluid, mainly used in waste heat recovery. Table 1 depicts some of the physical, safety, and environmental characteristics of the selected organic fluids.

Table 1. Characteristics of test candidate fluids.

\begin{tabular}{|c|c|c|c|c|c|c|c|c|}
\hline \multirow{2}{*}{ Refrigerant } & \multirow{2}{*}{$\begin{array}{l}\text { Chemical } \\
\text { Formula }\end{array}$} & \multirow{2}{*}{$\begin{array}{c}T_{c} \\
\left({ }^{\circ} \mathrm{C}\right)\end{array}$} & \multirow{2}{*}{$\begin{array}{c}p_{c} \\
\text { (bar) }\end{array}$} & \multirow{2}{*}{$\begin{array}{c}M_{W} \\
(\mathrm{gr} / \mathrm{mol})\end{array}$} & \multirow{2}{*}{$\begin{array}{l}T_{n, b} \\
\left({ }^{\circ} \mathrm{C}\right)\end{array}$} & \multicolumn{2}{|c|}{ Depletion } & \multirow{2}{*}{$\begin{array}{l}\text { Safety } \\
\text { Group }^{*}\end{array}$} \\
\hline & & & & & & ODP & GWP & \\
\hline $\mathrm{R}-123$ & $\mathrm{CHCl}_{2} \mathrm{CF}_{3}$ & 183.68 & 36.618 & 152.93 & 27.82 & 0.02 & 77 & B1 \\
\hline R-1233zd-E & $\mathrm{CF}_{3} \mathrm{CH}=\mathrm{CHCl}$ & 166.45 & 36.237 & 130.496 & 18.26 & 0.00034 & 7 & $\mathrm{~A} 1$ \\
\hline $\mathrm{R}-245 \mathrm{fa}$ & $\mathrm{CHF}_{2} \mathrm{CH}_{2} \mathrm{CF}_{3}$ & 153.86 & 36.51 & 134.048 & 15.05 & 0 & 1030 & B1 \\
\hline R-1234ze-E & $\mathrm{CF}_{3} \mathrm{CH}=\mathrm{CFH}$ & 109.36 & 36.349 & 114.053 & -18.97 & 0 & $<1$ & $\mathrm{~A} 2 \mathrm{~L}$ \\
\hline $\mathrm{R}-134 \mathrm{a}$ & $\mathrm{CH}_{2} \mathrm{FCF}_{3}$ & 101.06 & 40.593 & 102.0 & -26.07 & 0.005 & 1430 & $\mathrm{~A} 1$ \\
\hline R-290 & $\mathrm{C} 3 \mathrm{H} 8$ & 96.67 & 42.359 & 44.1 & -42.09 & 0 & 3.3 & A2 \\
\hline
\end{tabular}

*See Figure 1 for description.

Figure 1 illustrates the ANSI/ASHRAE Standard for the designation and safety classification of Refrigerants, [20].

Table 2 shows some of the thermal properties of candidate fluids at the evaporating and condensing temperatures. 


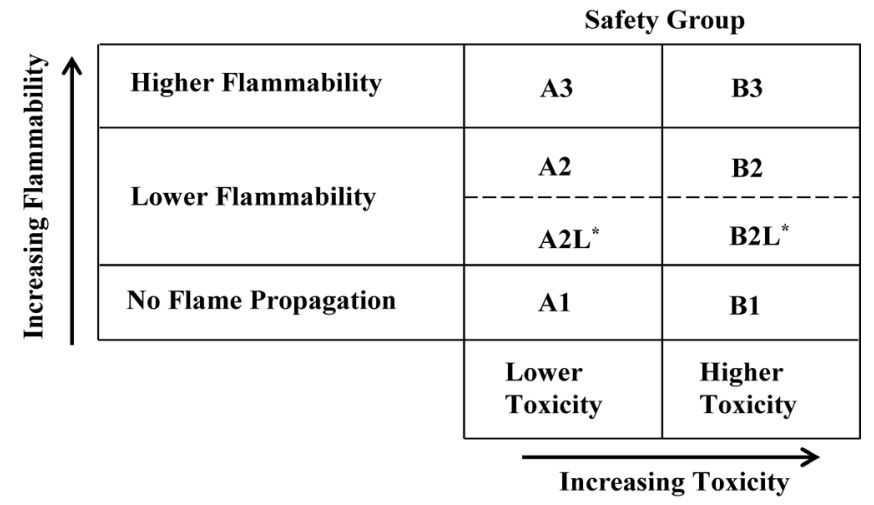

${ }^{\star} \mathrm{A} 2 \mathrm{~L}$ and B2L are lower flammability refrigerants with a maximum burning velocity $(10 \mathrm{~cm} / \mathrm{s})$.

Figure 1. Classification of safety groups for refrigerants, ANSI/ASHRAE standard [20].

Table 2. Thermodynamics properties of candidate working fluids.

\begin{tabular}{cccccccccc}
\hline & \multicolumn{2}{c}{$\begin{array}{c}\text { Pressure } \\
\text { Refrigerant }\end{array}$} & \multicolumn{2}{c}{$\begin{array}{c}\text { Liquid Density } \\
\left(\mathrm{kg} / \mathrm{m}^{3}\right)\end{array}$} & $\begin{array}{c}\text { Liquid Enthalpy } \\
(\mathrm{kJ} / \mathrm{kg})\end{array}$ & $\begin{array}{c}\text { Vapor Enthalpy } \\
(\mathrm{kJ} / \mathrm{kg})\end{array}$ & $\begin{array}{c}\dot{m} \\
(\mathrm{~kg} / \mathrm{s})\end{array}$ \\
\cline { 2 - 10 } & $45^{\circ} \mathrm{C}$ & $90^{\circ} \mathrm{C}$ & $45^{\circ} \mathrm{C}$ & $90^{\circ} \mathrm{C}$ & $45^{\circ} \mathrm{C}$ & $90^{\circ} \mathrm{C}$ & $45^{\circ} \mathrm{C}$ & $90^{\circ} \mathrm{C}$ & $10 \mathrm{~kW}$ \\
\hline R-123 & 1.824 & 6.2423 & 1411.43 & 1279.9 & 243.63 & 293.34 & 406.92 & 433.32 & 0.051 \\
R-1233zd-E & 2.521 & 8.3345 & 1212.8 & 1083.4 & 255.99 & 314.95 & 434.86 & 465.54 & 0.047 \\
R-245fa & 2.947 & 10.059 & 1282.05 & 1133.7 & 259.11 & 324.06 & 438.28 & 469.26 & 0.046 \\
R-1234ze-E & 8.764 & 24.755 & 1093.05 & 867.2 & 262.27 & 335.12 & 412.63 & 428.52 & 0.058 \\
R-134a & 11.602 & 32.442 & 1125.05 & 837.8 & 263.95 & 342.93 & 421.52 & 425.42 & 0.059 \\
R-290 & 15.315 & 37.731 & 461.36 & 315.79 & 319.27 & 490.06 & 616.15 & 618.6 & 0.033 \\
\hline
\end{tabular}

\subsection{Simple Organic Rankine Cycle}

Figure 2 illustrates a schematic diagram for a simple organic Rankine cycle. It composes of the principal components such as the evaporator, condenser, expander actuator, pump, and generator to convert the work output to electrical power.

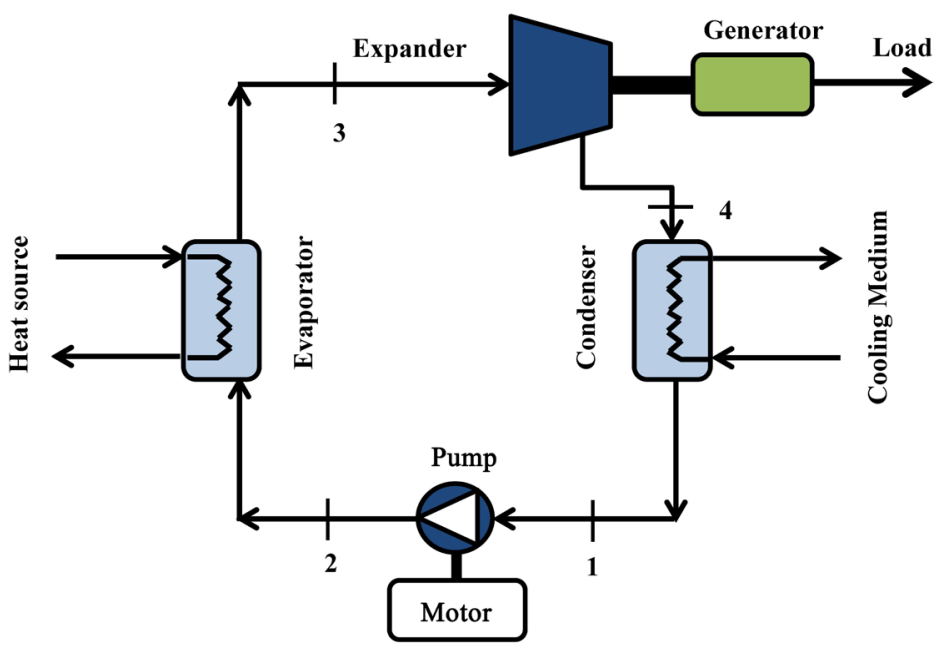

Figure 2. A schematic diagram for a simple Organic Rankine Cycle (SORC). 
Figure 3 represents a typical ( $T-s)$ diagram of the (SORC) unit.

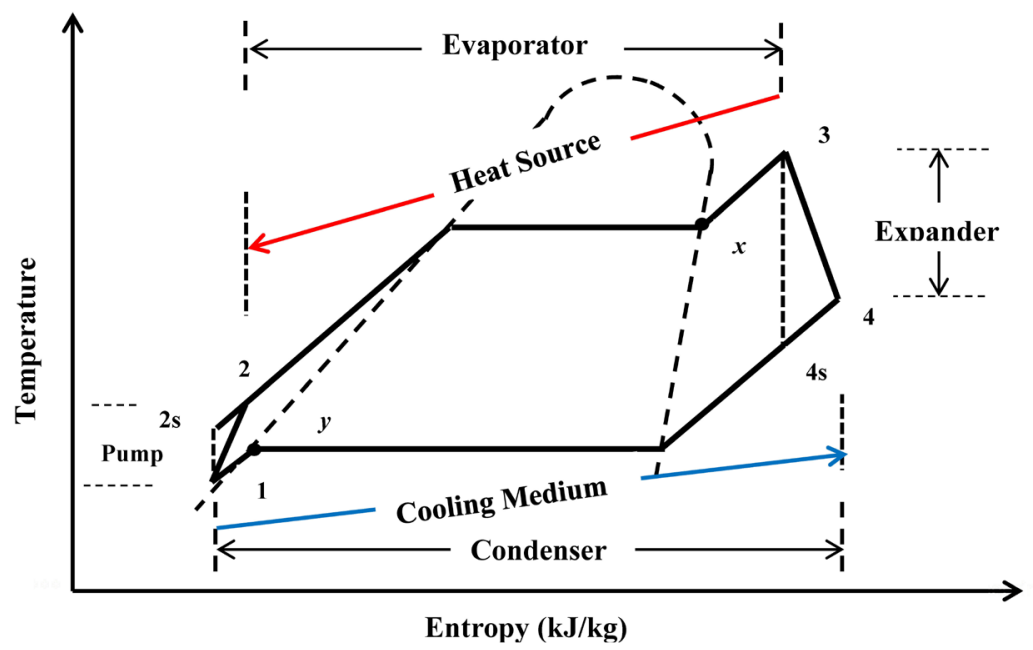

Figure 3. The T-s diagram of a simple Organic Rankine Cycle (SORC).

\subsection{Thermal Analysis}

Table 3 illustrates the thermal analysis of the Rankine cycle. The data analysis utilizes the general energy criteria deduced from the first law of thermodynamics for the evaporator, condenser, expander, and pump. The energy loss from the evaporator is negligible for excellent thermal insulation. Isentropic and volumetric

Table 3. Thermal analysis of the simple organic Rankine cycle (SORC).

Analysis


efficiencies of the expander and the isentropic pump's efficiency were set as $85 \%$.

The mass flow rate of the working fluid deduced from the knowledge of the nominal waste heat capacity. The mass flow rate of the working fluid expressed by:

$$
\dot{Q}_{\text {waste }}=\dot{m}\left(h_{g, \text { evap }}-h_{2}\right)
$$

At a heating capacity of $10 \mathrm{~kW}$ for preheating and vaporizing the working fluid in the evaporator at $90^{\circ} \mathrm{C}$ with zero superheat degree was considered. The value of the fluid mass flow rate remained constant for each candidate regardless of the superheat degree. Hence, the effect of a superheat degree on thermal performance could be analyzed. The total absorbed heat load by the fluid as it passes through the evaporator was calculated from:

$$
\begin{gathered}
\dot{Q}_{\text {evap }, t}=\dot{Q}_{\text {waste }}+\dot{Q}_{\text {sup }} \\
\varepsilon=\frac{\phi_{n}-\phi_{\text {ref }}}{\phi_{n}} \times 100
\end{gathered}
$$

Here, the subscriptions $(n)$ and ( $r e f)$ refer to the compared fluid and reference fluid respectively. The parameter $(\phi)$ refers to the required characteristic variable for comparison such as $\dot{W}_{\text {pump }}, \dot{W}_{\text {exp }}, \dot{Q}_{\text {eavp }}$, and $\eta_{\text {net }}$.

\subsection{Calculation Procedure}

The mathematical procedure for thermal analysis is represented in Figure 4.

\section{Results and Discussion}

\subsection{Energy Extraction}

Figure 5 depicts a comparison for the total absorbed heat by the working fluids from the waste heat source.

The results illustrate that the extracted heat from the waste by R-290 as a working fluid was higher than other fluids. R-123 fluid absorbs the lowest energy, and it was closer to that of the R-1233zd-E for the whole test range of superheat degrees. The discrepancies were 6\% - 13\%, 5\% - 10\%, 3\% - 7\%, 1\% - 2\% and $0.1 \%-0.6 \%$ for fluids R-290, R-134a, R-1234ze-E, R-245fa and R-1233zd-E respectively as they were compared to those of R-123 for the examined superheat degree range. These differences are mainly due to the discrepancy in the ability to absorb heat in the evaporator's superheated zone.

Figure 6 depicts the comparison of the extracted energy rate in the evaporator for various working fluids. The results showed that R-134a and R-290 obtained the highest energy values, and they approached values of $12 \mathrm{~kW}$ and $11 \mathrm{~kW}$ at superheat degrees of $15^{\circ} \mathrm{C}$ and $5^{\circ} \mathrm{C}$, respectively. R-245fa, R-1233zd-E, and $\mathrm{R}-123$ absorbed close values of energy for the examined superheat range; it was within $10.25-11 \mathrm{~kW}$.

Table 1 reveals that R-290 possesses the lowest critical temperature among other fluids, and R-123 has the highest critical temperature magnitude. These 


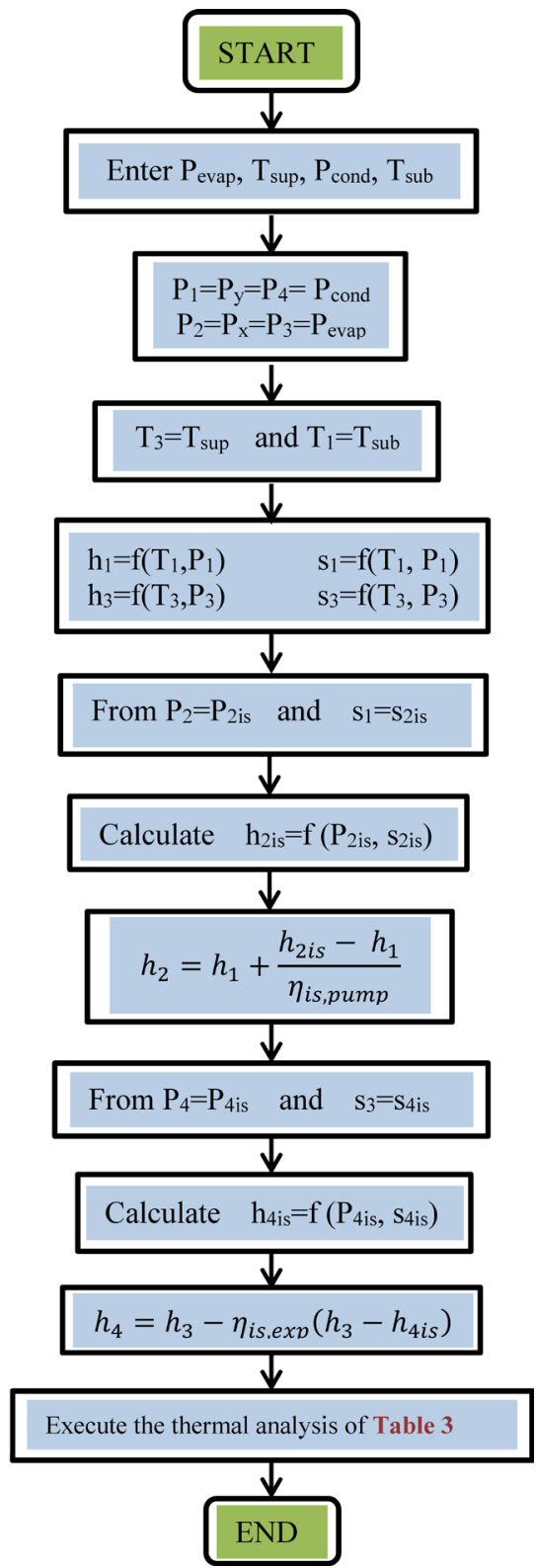

Figure 4. Thermal analysis flowchart for the simple organic Rankine cycle (SORC).

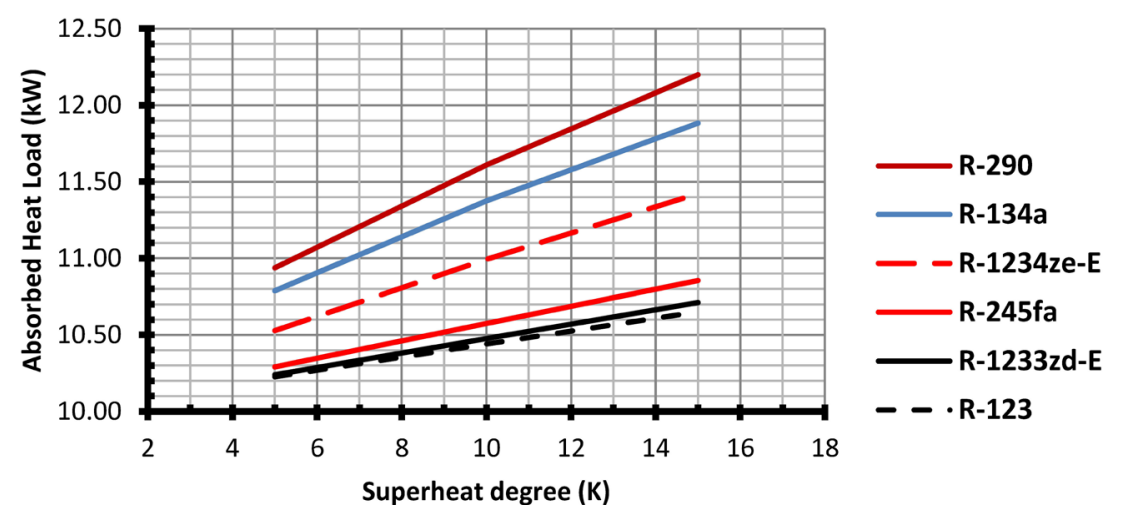

Figure 5. A comparison of the extracted waste heat in the evaporator for the (SORC) for a nominal heat load of $10 \mathrm{~kW}$. 


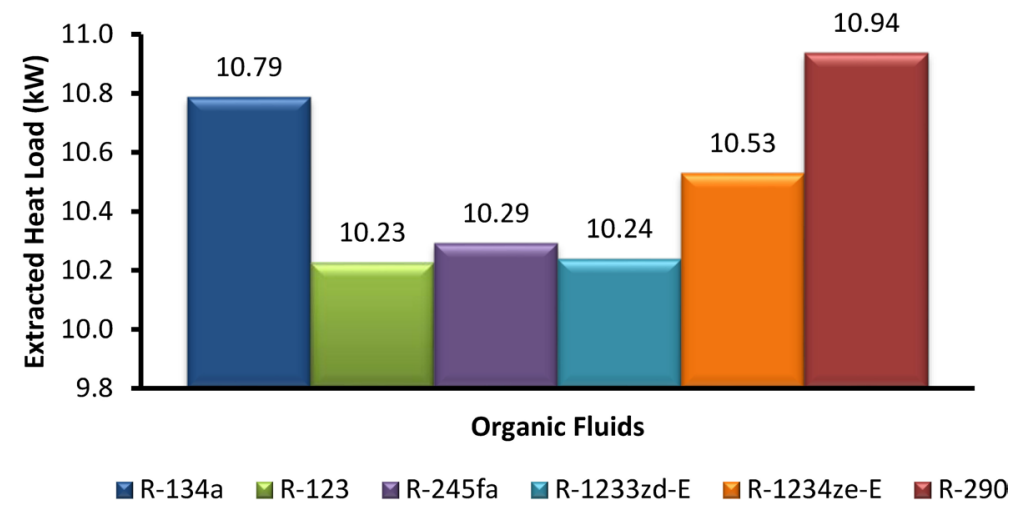

(a)

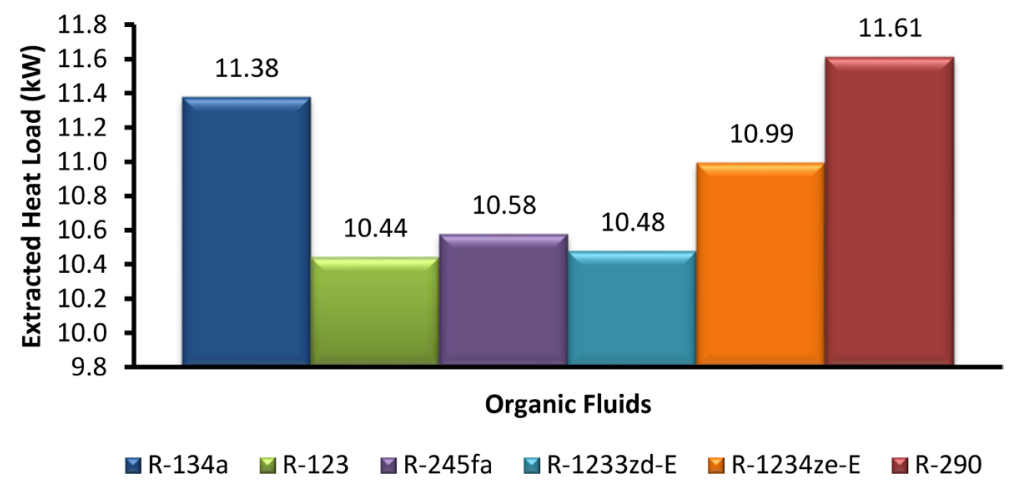

(b)

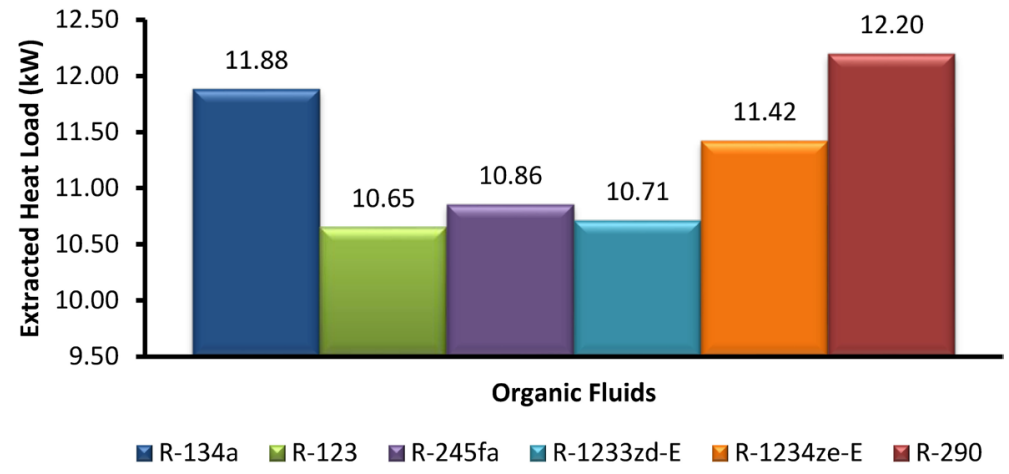

(c)

Figure 6. A comparison of the extracted waste heat load at different superheat degrees and nominal cycle heat load of $10 \mathrm{~kW}$. (a) Extracted heat load at $5^{\circ} \mathrm{C}$; (b) Extracted heat load at $10^{\circ} \mathrm{C}$; (c) Extracted heat load at $15^{\circ} \mathrm{C}$.

results indicate that the critical temperature has an important impact on the fluid ability to extract heat from a waste heat source; it increases as the fluid critical temperature increases, Figure 6.

\subsection{Cycle Power Output}

Figure 7 shows a comparison for the cycle net power output of test working fluids at various superheat degrees and nominal evaporator capacity of $10 \mathrm{~kW}$ (SORC). The trend of the results revealed that R-290 and R-1233zd-E possess the highest and lowest numerical values of $\left(\dot{W}_{\text {net }}\right)$ respectively. It is defined as: 


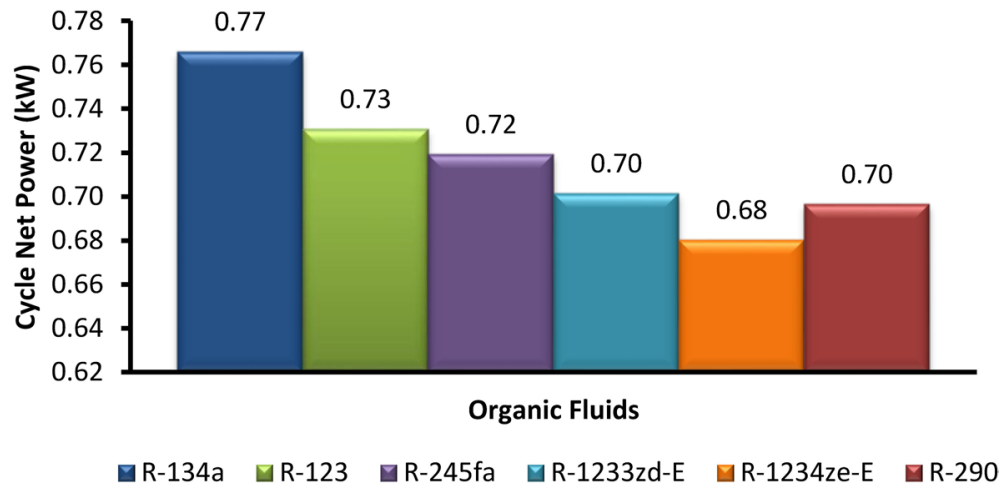

(a)

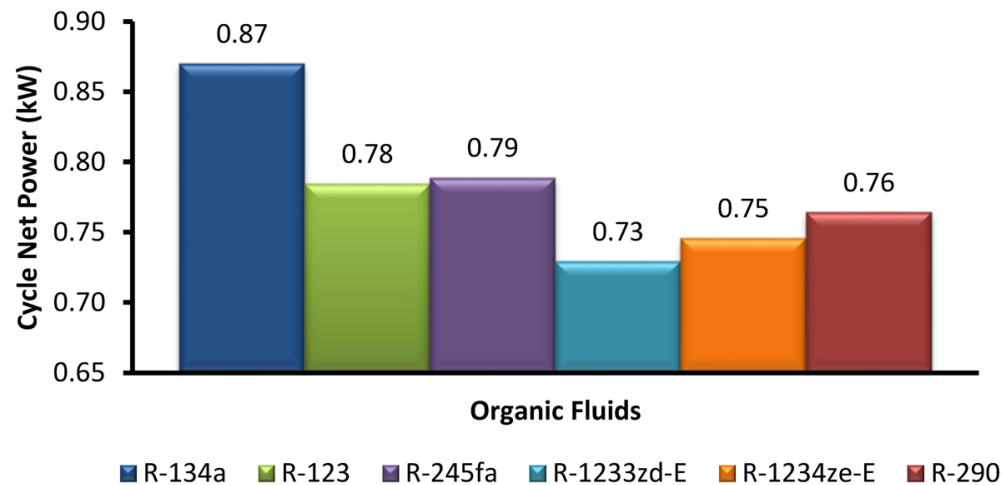

(b)

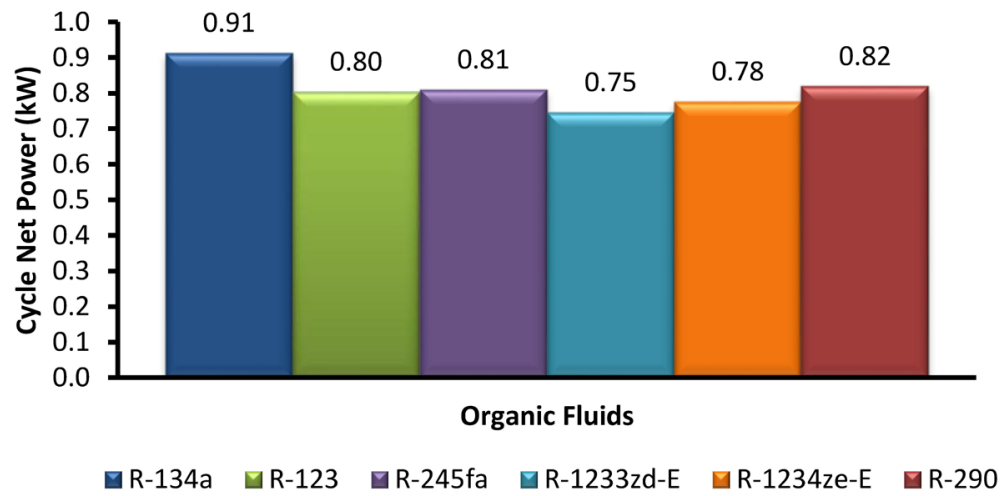

(c)

Figure 7. Cycle net power output comparison of test fluids at different superheat degrees and nominal cycle heat load of $10 \mathrm{~kW}$. (a) Net power output at $5^{\circ} \mathrm{C}$; (b) Net power output at $10^{\circ} \mathrm{C}$; (c) Net power output at $15^{\circ} \mathrm{C}$

$$
\dot{W}_{\text {net }}=\dot{W}_{\text {exp }}-\dot{W}_{\text {pump }}
$$

R-134a produced a higher cycle net power by $8 \%$ - $18 \%$ than R-1233zd-E for the examined superheat degree range. The R-134a generated net output power of $0.77 \mathrm{~kW}$ and $0.91 \mathrm{~kW}$ at superheat degrees of $5^{\circ} \mathrm{C}$ and $15^{\circ} \mathrm{C}$, respectively. R-123, R-245fa, R-1234ze-E, R-290, and R-1233zd-E fluids showed close values of cycle net power; they were in the range of $0.75-0.82 \mathrm{~kW}$ and $0.68-0.73 \mathrm{~kW}$ at $15^{\circ} \mathrm{C}$ and $5^{\circ} \mathrm{C}$ superheat degree respectively. The net power cycle output increases as the gas superheat increases at the expander entrance port. R-134a, R-290, R-1234ze-E, 
R-245fa, R-123, and R-1233zd-E showed a rise in the net power output by $16 \%$, $15 \%, 12 \%, 11 \%, 9 \%$, and $6 \%$ respectively when the fluid superheat degree was increased from $5^{\circ} \mathrm{C}$ to $15^{\circ} \mathrm{C}$.

Figure 8 depicts a comparison for the expander power output of various fluids at $15^{\circ} \mathrm{C}$ superheat degree. $\mathrm{R}-290$ produced $1 \mathrm{~kW}$, which was the highest expander power output among other examined fluids. However, it has produced a lower cycle net power than that of R-134a for the test operating conditions. This is because it has consumed more power to run the pump than that of R-134a.

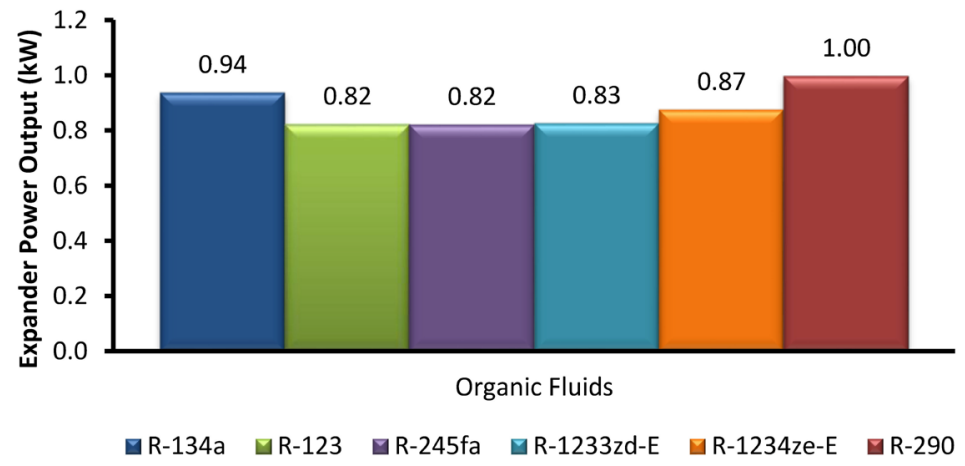

Figure 8. Expander power output comparison of test fluids at $15^{\circ} \mathrm{C}$ superheat degrees and nominal cycle heat load of $10 \mathrm{~kW}$.

The data declare that the expander output power of the cycle increases as the superheat degree rises for all test fluids. The numerical figures revealed that as the superheat degree was increased from $5^{\circ} \mathrm{C}$ to $10^{\circ} \mathrm{C}$, the augmentation of the expander power was higher than that of the second level of superheating between $10^{\circ} \mathrm{C}$ and $15^{\circ} \mathrm{C}$. The increased percentages were ranged between $0.1 \%-5 \%$ and $3 \%-12 \%$ for the superheat degree ranges of $10^{\circ} \mathrm{C}$ to $15^{\circ} \mathrm{C}$ and $5^{\circ} \mathrm{C}$ to $10^{\circ} \mathrm{C}$ respectively. R-245fa, 1233zd-E, and R-123 exhibited the lowest expander output as $0.83 \mathrm{~kW}$ at $15^{\circ} \mathrm{C}$ superheat degree. The $1233 \mathrm{zd}-\mathrm{E}, 1234 \mathrm{ze}-\mathrm{E}, \mathrm{R}-245 \mathrm{fa}$, and $\mathrm{R}-123$ fluids tended to produce close results for the expanders' power output.

\subsection{Pumping Flow Rate}

At a nominal extracted heat from a waste energy source of $10 \mathrm{~kW}$, the required volumetric flow rate of test fluids is compared in Figure 9. Under similar operating

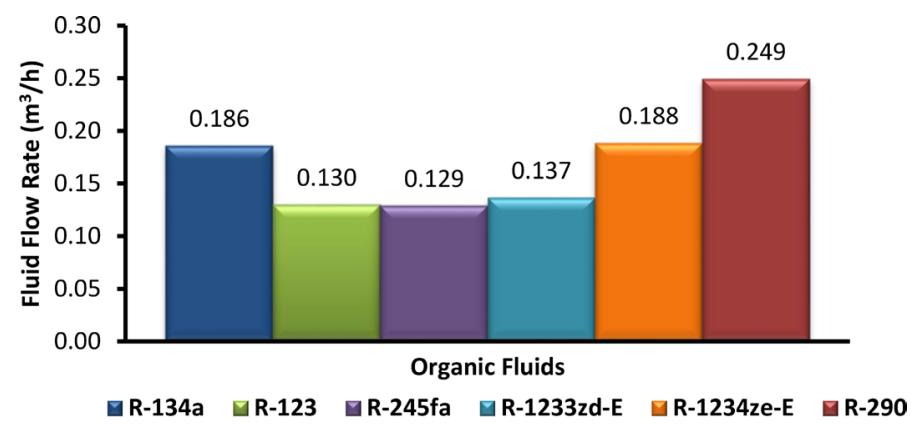

Figure 9. Pumping volumetric flow rate comparison of various fluids at nominal cycle heat load of $10(\mathrm{~kW})$. 
conditions of evaporating temperature, R-134a, R-290, and R-1234ze-E cycles circulated the highest flow rates, it fell in the range of $0.19-0.25 \mathrm{~m}^{3} / \mathrm{hr}$. R-1233zd-E, R-245fa, and R-123 circulated close values of the fluid flow rates in the range of $0.13-0.14 \mathrm{~m}^{3} / \mathrm{hr}$.

The results showed that the R-1233zd-E (SORC) needed to pump volumetric flow rates higher than those of R-123 and R-245fa by 5\% and $6 \%$ respectively to attend the same output power from the expander. The consumed power by the pump was comparable between different fluids. R-290 needed the highest power consumption to run the system; it approached a value of $0.18 \mathrm{~kW}$.

\subsection{Cycle Net Thermal Efficiency}

Figure 10 illustrates a comparison of cycle thermal efficiency for the examined organic fluids at different superheats. The maximum thermal efficiency was attained when circulating R-134a, R-123, and R-245fa, it was within the range of $7.5 \%-7.7 \%$ at $15^{\circ} \mathrm{C}$ superheat. The corresponding thermal efficiency values of other examined fluids fell in the range of $6.7 \%-7 \%$ at $15^{\circ} \mathrm{C}$ superheat. The lowest cycle net thermal efficiency was achieved at the low superheat degree of $5^{\circ} \mathrm{C}$ for all examined fluids; it fell in the range of $6.4 \%-7.1 \%$. R-134a exhibited the maximum predicted cycle net thermal efficiency and reached a $7.7 \%$ value at $15^{\circ} \mathrm{C}$. Whereas R-290 and R-1234ze-E showed the lowest range of cycle net

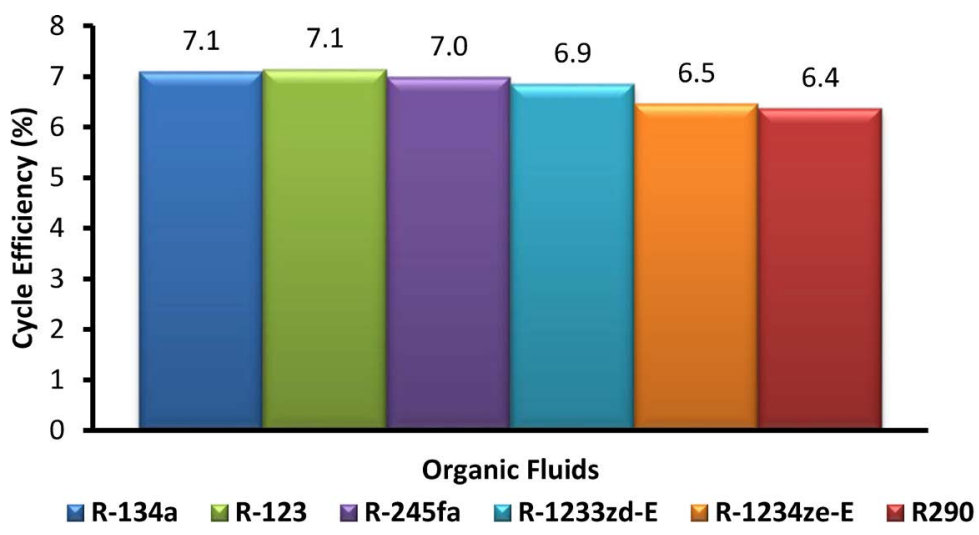

(a)

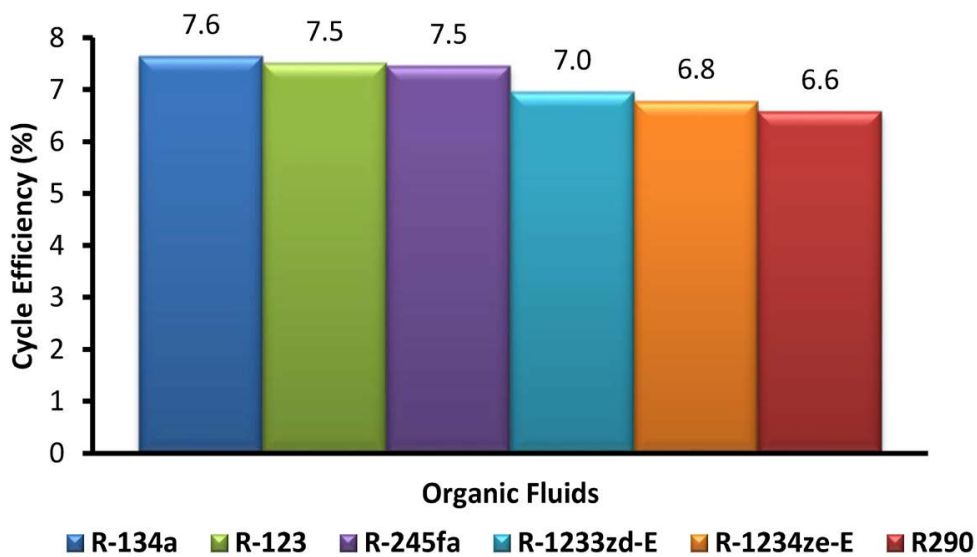

(b) 


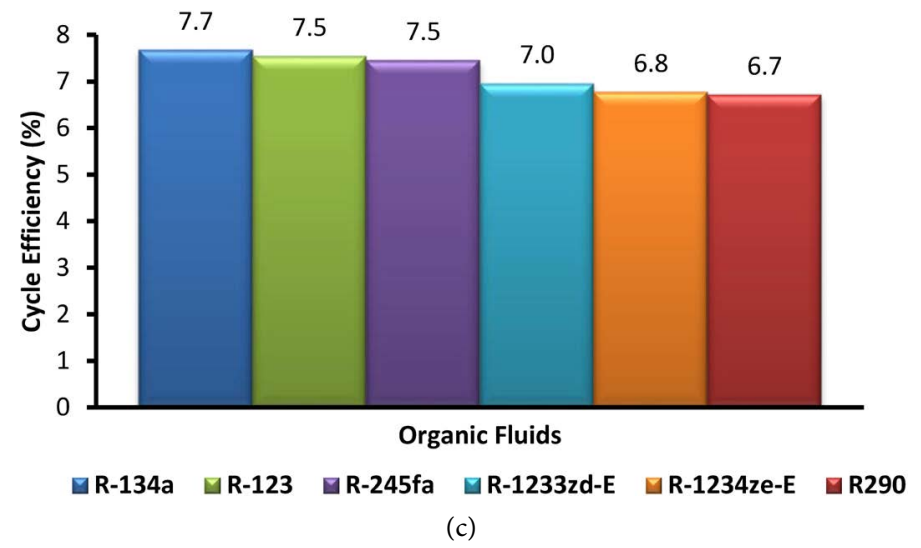

Figure 10. Cycle net thermal efficiency comparison of test fluids at different superheat degrees. (a) $\Delta T_{\text {sup }}=5^{\circ} \mathrm{C}$; (b) $\Delta T_{\text {sup }}=10^{\circ} \mathrm{C}$; (c) $\Delta T_{\text {sup }}=15^{\circ} \mathrm{C}$.

thermal efficiency among other tested fluids, it was $6.7 \%-6.8 \%$. This value was close to the predicted value of R-1233zd-E as $7 \%$ at $15^{\circ} \mathrm{C}$ superheat degree.

The predicted cycle thermal efficiency values for R-134a, R-123, R-245fa, R-1233zd-E, and R-1234ze-E were higher than those of R-290 by $10 \%-14 \%$, $11 \%-12 \%, 9 \%-12 \%, 4 \%-7 \%$ and $1 \%-3 \%$ respectively. The cycle net thermal efficiency revealed a slight dependence on the superheat degree. Increasing the vapor temperature from $5^{\circ} \mathrm{C}$ to $15^{\circ} \mathrm{C}$ has improved the cycle efficiency by $7.5 \%$, $6 \%$, and $1.5 \%$ for R-134a, R-245fa, and R-1233zd-E respectively. The corresponding enhancement was $5 \%$ for other tested fluids.

R-290 showed an acceptable thermal performance; it is a proper alternative to the conventional fluids due to its attractive environmental characteristics, Table 1 and Figure 10. Its thermal efficiency was very close to R-1233zd-E and R-1234ze-E for the examined range of operating conditions. Although R-290 exhibited a close thermal efficiency to R-1233zd-E and R-1234ze-E, the results showed that R-290 extracted more heat rates from the energy source. R-290 extracted heat rates, about $6.4 \%, 9.7 \%$, and $12 \%$ higher than those of R-1233zd-E at superheat degrees of $5^{\circ} \mathrm{C}, 10^{\circ} \mathrm{C}$, and $15^{\circ} \mathrm{C}$ respectively, Figure 6 . The same conclusion is valid for the case of R-1233zd-E and R-1234ze-E (SORC). Although the R-1233zd-E and R-1234ze-E produced similar cycle net thermal efficiency, the results showed that these fluids extracted different heat rates from the low-temperature grade energy source. The extracted heat loads by R-1234ze-E fluid were $6 \%, 4.6 \%$, and $2.8 \%$ greater than those of R-1233zd-E at superheat degrees of $15^{\circ} \mathrm{C}, 10^{\circ} \mathrm{C}$, and $5^{\circ} \mathrm{C}$ respectively.

The expander device's volumetric efficiency plays a vital role in the thermal assessment of the organic Rankine cycle. Increasing the volumetric efficiency by $10 \%$ has improved the (SORC) thermal efficiency by the range of $10 \%-12 \%$ for the test fluids and superheat degree range. The thermal efficiencies of R-134a, R-123, and R-245fa showed an enhancement of 10\%. R-1233zd-E and R-1234ze-E thermal efficiencies were increased by $11 \%$, and R-290 thermal efficiency was improved by $11 \%-12 \%$, Figure 11 . 


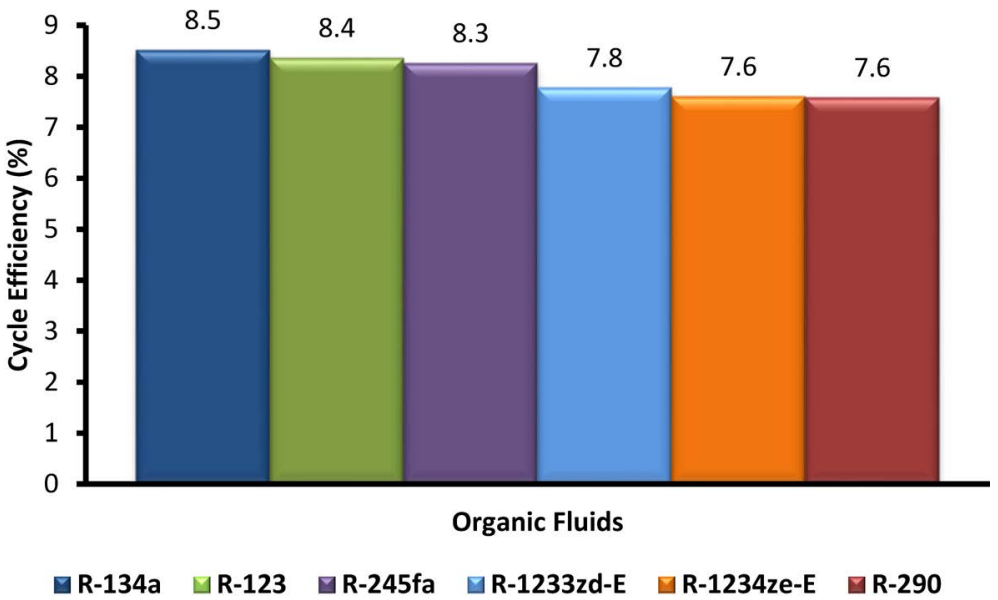

Figure 11. Cycle net thermal efficiency comparison at $\Delta T_{\text {sup }}=15^{\circ} \mathrm{C}$ with expander volumetric efficiency of $94 \%$.

\section{Conclusions}

The present work showed that the selected fluids work well to extract the waste energy at low-temperature grade. The amount of extracted energy revealed a dependence on the temperature of the circulated fluid. The working fluids R-290 and R-123 extracted the highest and lowest energy amounts from the waste source. The absorbed heat discrepancies were $6 \%-13 \%, 5 \%-10 \%, 3 \%-7 \%, 1 \%$ - $2 \%$, and $0.1 \%-0.6 \%$ for fluids R-290, R-134a, R-1234ze-E, R-245fa and $\mathrm{R}-1233 \mathrm{zd}-\mathrm{E}$ respectively as they were compared to those of R-123 for the examined superheat degree range.

The R-134a fluid produced the highest net output power of the (SORC); it was as $0.77 \mathrm{~kW}$ and $0.91 \mathrm{~kW}$ at superheat degrees of $5^{\circ} \mathrm{C}$ and $15^{\circ} \mathrm{C}$, respectively. The other fluids showed close values of cycle net power; they were in the range of $0.75-0.82 \mathrm{~kW}$ and $0.68-0.73 \mathrm{~kW}$ at $15^{\circ} \mathrm{C}$ and $5^{\circ} \mathrm{C}$ superheat degrees, respectively. R-134a, R-290, R-1234ze-E, R-245fa, R-123, and R-1233zd-E showed a rise for the net power output by $16 \%, 15 \%, 12 \%, 11 \%, 9 \%$, and $6 \%$ respectively when the fluid superheat degree was increased from $5^{\circ} \mathrm{C}$ to $15^{\circ} \mathrm{C}$.

The predicted cycle thermal efficiency values for R-134a, R-123, R-245fa, R-1233zd-E, and R-1234ze-E were higher than those of R-290 by $10 \%-14 \%$, $11 \%-12 \%, 9 \%-12 \%, 4 \%-7 \%$ and $1 \%-3 \%$, respectively. The cycle net thermal efficiency revealed a dependence on the superheat degree. Increasing the vapor temperature from $5^{\circ} \mathrm{C}$ to $15^{\circ} \mathrm{C}$ has improved the cycle efficiency by $7.5 \%, 6 \%$, and $1.5 \%$ for R-134a, R-245fa, and R-1233zd-E, respectively. The corresponding enhancement was about $5 \%$ for other tested fluids. Two categories for the cycle net thermal efficiency were recognized at the present research. The first one included the high-efficiency level; it contains R-134a, R-123, and R-245fa fluids. R-1233zd-E, R-1234ze-E, and R-290 occupied the second thermal efficiency level. The volumetric efficiency of the expander has an important influence on the net cycle thermal efficiency. Increasing its value by $10 \%$ improved the thermal efficiency by the range of $10 \%-12 \%$ for the examined working fluids. 
R-290 exhibited thermal efficiencies close to R-1233zd-E and R-1234ze-E in the superheat degree range of $5^{\circ} \mathrm{C}-15^{\circ} \mathrm{C}$. Hence, the hydrocarbon fluid R-290 is a suitable alternative candidate to the conventional fluids R-245fa and $\mathrm{R}-1233 \mathrm{zd}-\mathrm{E}$ in the basic organic Rankine cycle (SORC) with a little more safety precautions.

\section{Acknowledgements}

The author would like to thank the Laboratoire Énergies \& Mécanique Théorique et Appliquée (LEMTA) of the University of Lorraine for their valuable support. Thanks are also extended to the administration of (PAUSE) program of Collège de France for allowing the author to pursue his research activities.

\section{Conflicts of Interest}

The author declares no conflicts of interest regarding the publication of this paper.

\section{References}

[1] Thekdi, A.C. and Nimbalkar, S.U. (2014) Industrial Waste Heat Recovery: Potential Applications, Available Technologies and Crosscutting R \& D Opportunities. Technical Report, ORNL/TM-2014/622, USA. https://doi.org/10.2172/1185778

[2] Badr, O., Probert, S.D. and O'Callaghan, P.W. (1985) Selecting a Working Fluid for a Rankine-Cycle Engine. Applied Energy, 21, 1-42. https://doi.org/10.1016/0306-2619(85)90072-8

[3] Yamamoto, T., Furuhata, T., Arai, N. and Mori K. (2001) Design and Testing of the Organic Rankine Cycle. Energy, 26, 239-251. https://doi.org/10.1016/S0360-5442(00)00063-3

[4] Chen, Y., Lundqvist, P., Johansson, A. and Platell, P. (2006) A Comparative Study of the Carbon Dioxide Transcritical Power Cycle Compared with an Organic Rankine Cycle with R123 as Working Fluid in Waste Heat Recovery. Applied Thermal Engineering, 26, 2142-2147. https://doi.org/10.1016/j.applthermaleng.2006.04.009

[5] Tchanche, B.F., Lambrinos, G., Frangoudakis, A. and Papadakis, G. (2011) Low-Grade Heat Conversion into Power Using Organic Rankine Cycles-A Review of Various Applications. Renewable \& Sustainable Energy Reviews, 15, 3963-3979. https://doi.org/10.1016/j.rser.2011.07.024

[6] Vignesh, P., Suresh, S. and Grashin, C.J. (2018) Issues, Comparisons, Turbine Selections and Applications-An Overview in Organic Rankine Cycle. Energy Conversion and Management, 166, 474-488.

https://doi.org/10.1016/j.enconman.2018.04.058

[7] Le, V.L., Kheiri, A., Feidt, M. and Pelloux-Prayer, S. (2014) Thermodynamic and Economic Optimizations of a Waste Heat to Power Plant Driven by a Subcritical ORC (Organic Rankine Cycle) Using Pure or Zeotropic Working Fluid. Energy, 78, 622-638. https://doi.org/10.1016/j.energy.2014.10.051

[8] Astolfi, M., Diega, L.N., Romano, M.C., Merlo, U., Filippini, S. and Macchi, E. (2017) Application of The Novel "Emeritus" Air Cooled Condenser In Geothermal ORC. Energy Procedia, 129, 479-486. https://doi.org/10.1016/j.egypro.2017.09.164

[9] Shengjun, Z., Huaixin, W. and Tao, G. (2011) Performance Comparison and Para- 
metric Optimization of Subcritical Organic Rankine Cycle (ORC) and Transcritical Power Cycle System for Low-Temperature Geothermal Power Generation. Applied Energy, 88, 2740-2754. https://doi.org/10.1016/j.apenergy.2011.02.034

[10] Yuan, P. and Zhang, C. (2019) Comparison on Thermodynamic Performances between Basic and Regenerative Sub-Critical Organic Rankine Cycles Coupled with Low Grade Heat Source. IOP Conference Series: Materials Science and Engineering, 473, Article ID: 012031. https://doi.org/10.1088/1757-899X/473/1/012031

[11] Vankeirsbilck, I., Vanslambrouck, B., Gusev, S. and De Paepe M. (2011) Organic Rankine Cycle as Efficient Alternative to Steam Cycle for Small Scale Power Generation. 8th International Conference on Heat Transfer, Fluid Mechanics and Thermodynamics (HEFAT2011), Pointe Aux Piments, Mauritius, 11-13 July 2011, 785-792.

[12] Datla, B.V. and Brasz, J.J. (2014) Comparing R1233zd And R245fa for Low Temperature ORC Applications. International Refrigeration and Air Conditioning Conference, Purdue, 14-17 July 2014, Paper 1524. http://docs.lib.purdue.edu/iracc/1524

[13] Molés, F., Navarro-Esbrí, J., Peris, B., Mota-Babiloni, A., Barragán-Cervera, Á. and Kontomaris, K.K. (2014) Low GWP Alternatives to HFC-245fa in Organic Rankine Cycles for Low Temperature Heat Recovery: HCFO-1233zd-E and HFO-1336mzz-Z. Applied Thermal Engineering, 71, 204-212. https://doi.org/10.1016/j.applthermaleng.2014.06.055

[14] Heberle, F., Jahrfeld, T. and Brüggemann, D. (2015) Thermodynamic Analysis of Double-Stage Organic Rankine Cycles for Low-Enthalpy Sources Based on a Case Study for (5.5) MWe Power Plant Kirchstockach (Germany). Proceedings World Geothermal Congress, Melbourne, Australia, 19-25 April 2015, 1-10.

[15] Li, L., Ge, Y.T., Luo, X. and Tassou, S.A. (2016) Thermodynamic Analysis and Comparison between $\mathrm{CO}_{2}$ Transcritical Power Cycles and R245fa Organic Rankine Cycles for Low Grade Heat to Power Energy Conversion. Applied Thermal Engineering, 106, 1290-1299. https://doi.org/10.1016/j.applthermaleng.2016.06.132

[16] Li, L., Ge, Y.T., Luo, X. and Tassou, S.A. (2017) Experimental Investigations into Power Generation with Low Grade Waste Heat and R245fa Organic Rankine Cycles (ORCs). Applied Thermal Engineering, 115, 815-824. https://doi.org/10.1016/j.applthermaleng.2017.01.024

[17] Kong, R., Deethayat, T., Asanakham, A., Vorayos, N. and Kiatsiriroat, T. (2019) Thermodynamic Performance Analysis of a R245fa Organic Rankine Cycle (ORC) with Different Kinds of Heat Sources at Evaporator. Case Studies in Thermal Engineering, 13, Article ID: 100385. https://doi.org/10.1016/j.csite.2018.100385

[18] Surindra, M.D., Caesarendra, W., Prasetyo, T., Mahlia, T.M. and Taufik (2019) Comparison of the Utilization of $110^{\circ} \mathrm{C}$ and $120^{\circ} \mathrm{C}$ Heat Sources in a Geothermal Energy System Using Organic Rankine Cycle (ORC) with R245fa, R123, and Mixed-Ratio Fluids as Working Fluids. Processes, 7, 113. https://doi.org/10.3390/pr7020113

[19] Da Cunha, A.F.V. and Souza, S.L.S. (2020) Analysis of R134a Organic Regenerative Cycle. Journal of Power and Energy Engineering, 8, 32-45. https://doi.org/10.4236/jpee.2020.85003

[20] (2016) ANSI/ASHRAE Standard 34, Designation and Safety Classification of Refrigerants. 


\section{Nomenclature}

$\begin{array}{ll}\text { Parameter } & \text { Definition } \\ h & \text { Fluid specific enthalpy, }(\mathrm{kJ} / \mathrm{kg}) \\ \dot{m} & \text { Fluid mass flow rate, }(\mathrm{kg} / \mathrm{s}) \\ P & \text { Fluid working pressure, }(\mathrm{bar}) \\ \dot{Q} & \text { Heat transfer rate, }(\mathrm{kW}) \\ s & \text { Fluid specific entropy, }(\mathrm{kJ} / \mathrm{kg}) \\ T & \text { Fluid temperature, }\left({ }^{\circ} \mathrm{C}\right) \\ \dot{W} & \text { Power, }(\mathrm{kW})\end{array}$

\section{Subscription}

$\begin{array}{ll}\begin{array}{ll}\text { Parameter } \\ \text { cond }\end{array} & \text { Definition } \\ \text { evap } & \text { Condenser } \\ \text { exp } & \text { Evaporator } \\ g & \text { Expander } \\ \text { is } & \text { Gas condition } \\ n & \text { Isentropic } \\ \text { net } & \text { Fluid } \\ \text { pump } & \text { Net value } \\ \text { ref } & \text { Feed pump } \\ \text { sub } & \text { Reference fluid } \\ \text { sup } & \text { Subcooled liquid } \\ t & \text { Superheated vapor } \\ \text { vol } & \text { Total } \\ \text { waste } & \text { Volumetric } \\ \text { Greek Letter } \\ \varepsilon & \text { Waste heat source } \\ \eta & \text { Deviation or enhancement percentage, (\%) } \\ \phi & \text { Cycle thermal efficiency, (\%) } \\ & \text { Characteristic parameter. }\end{array}$

